\title{
Heterosis and Inbreeding Depression for Seed Cotton Yield and Yield Attributing Traits in Intrahirsutum (G. hirsutum L. X G. hirsutum L.) Hybrids of Cotton
}

\author{
Aman Tigga*, S.S. Patil, Vinayak Edke, Utpal Roy and Ashutosh Kumar \\ Department of Genetics and Plant Breeding, College of Agriculture, University of Agricultural \\ Sciences, Dharwad-580005, Karnataka, India \\ *Corresponding author
}

\section{A B S T R A C T}

\begin{tabular}{|l|}
\hline K e y w o r d s \\
$\begin{array}{l}\text { Heterobeltiosis, } \\
\text { Mid-parent } \\
\text { heterosis, Non- } \\
\text { additive gene } \\
\text { action, Inbreeding } \\
\text { depression. }\end{array}$ \\
\hline Article Info \\
\hline $\begin{array}{l}\text { Accepted: } \\
\text { 23 September } 2017 \\
\text { Available Online: } \\
\text { 10 October } 2017\end{array}$ \\
\hline
\end{tabular}

\section{Introduction}

Cotton, the "king of fibre", is an important cash crop having profound influence on economics and social affairs of the country. In India, cotton is the most important commercial crop, belonging to the family Malvaceae and the genus Gossypium. It has diversity in categories of cultivated species such as diploids and tetraploids, of which only four species (Gossypium arboreum L., Gossypium herbaceum L., Gossypium hirsutum L. and Gossypium barbadense L.) are cultivated. Among the four cultivated species, upland cotton (Gossypium hirsutum L.) is known for its production potential, while Egyptian cotton (Gossypium barbadense L.) is known for high fibre quality. The intraspecific hybrids of $G$. hirsutum L. have good fibre properties as well as higher yields.

The presence of non-additive gene action or overdominance is the primary justification for initiating a hybrid breeding program.

The present study was undertaken to find out the extent of heterosis for the seed cotton yield and its component characters in upland cotton (Gossypium hirsutum L.). 


\section{Materials and Methods}

The present study was conducted at Main Agricultural Research Station, Dharwad Farm, University of Agricultural Sciences Dharwad during Kharif 2014-15. The parent material used in the study comprised of two hybrids involving four parents. The resulting two $F_{1} s$ and four parents were grown in randomized block rows with two replication, having two rows in each replication of $5.4 \mathrm{~m}$ length, along with populations used for other studies during kharif 2015-16. Here, spacing in between rows and plant to plant was $90 \mathrm{~cm}$ and $45 \mathrm{~cm}$ respectively. Recommended agronomic practices were followed to raise the crop. Data were recorded for seed cotton yield, number of bolls per plant, boll weight, ginning outturn lint index, seed index, number of sympodia per plant and plant height. Population size of $\mathrm{P}_{1}, \mathrm{P}_{2}$ and $\mathrm{F}_{1}$ was 30 and 400 for $F_{2}$ in both cross combination. Calculation were carried out according to the formulae given by Fehr (1987).

\section{Results and Discussion}

Results on mid-parent and better parent heterosis for eight characters are presented in Table 1 . The trait seed cotton yield per plant showed high significant positive heterosis over mid-parent $(54.26 \%)$ and over better parent $(40.79 \%)$ in cross DSMR10 $\mathrm{x}$ DRCR4, also combination DRGR2572 X M5 also showed high significant positive heterosis over mid-parent $(55.33 \%)$ and over better parent $(40.27 \%)$. Similar results were reported by Ahuja and Tuteja (2000), Tuteja et al., (2004), Maisuria et al., (2007) and Wankhade et al., (2009). Significant inbreeding depression was observed from $F_{1}$ to $\mathrm{F}_{2}$ for cross DSMR10 x DRCR4 (37.21\%) and DRGR2572 X M5 (29.82 \%). These results are in conformity with Pradeep, et al., (2003), Shastri (2003) and Kumari et al., (2009).
The character number of bolls per plant showed high significant positive heterosis over mid-parent $(35.45 \%)$ and over better parent (45.56\%) in cross DSMR10 x DRCR4 indicating the predominance of non additive gene action. In cross DRGR2572 X M5 heterosis over mid-parent (54.15\%) and over better parent $(46.34 \%)$ were highly significant. Positive heterosis over better parent was reported by Tuteja et al., (2004), Kapoor et al., (2002) and Patil and Meshram (2002) for this trait. Inbreeding depression for this trait was significant in $\mathrm{F}_{2}$ of both crosses, $35.45 \%$ for cross DSMR10 x DRCR4 and $20.31 \%$ in cross DRGR2572 X M5. Significantly high inbreeding depression was noticed in these crosses indicating nonadditive gene action and this high inbreeding depression was associated with high heterotic effect in the diverse cross for this trait. Similar result was noticed by Anuradha (1997).

Results for boll weight showed significance for both mid-parent heterosis $(3.60 \%)$ and heterobeltiosis $(-3.42 \%)$ were found to be significant in negative direction. In cross DSMR10 x DRCR4 and in cross DRGR2572 $\mathrm{X}$ M5 mid-parent heterosis (-5.65\%) and heterobeltiosis $(-8.13 \%)$ were significant. Inbreeding depression from $F_{1}$ to $F_{2}$ was highly significant in cross DSMR $10 \quad \mathrm{x}$ DRCR4 $(6.98 \%)$ and in cross DRGR2572 X M5 it was non-significant. Inbreeding depression was significant in cross DSMR10 $x$ DRCR4 the generations indicating the predominance of dominant gene action. Similar results were obtained by Kumari et al., (2009).

For ginning out-turn both mid-parent heterosis $(9.89 \%)$ and heterobeltiosis $(9.62$ $\%$ ) were found to be highly significant in cross DSMR10 x DRCR4. In cross DRGR2572 X M5 mid-parent heterosis (7.35 $\%)$ and heterobeltiosis $(8.50 \%)$ were also 
significant. Patel and Pethani (1998) and Tuteja et al., (2000) reported similar results. Significant and similar level of inbreeding depression was observed in both crosses 7.51 $\%$ in cross DSMR10 x DRCR4 and $7.49 \%$ in DRGR2572 X M5. Similar results were noticed by Shastri (2003) and Kumari et al., (2009).

The trait lint index showed significant positive heterosis over mid-parent $(31.38 \%)$, heterobeltiosis (28.54\%) in cross DSMR10 $\mathrm{x}$ DRCR4 and in cross DRGR2572 X M5 both heterosis over mid-parent $(32.53 \%)$ and heterobeltiosis $(33.81 \%)$ were highly significant. Similar results were observed by Dukre et al., (2009). The inbreeding depression was highly significant in positive direction indicating the presence of nonadditive gene action in both crosses DSMR10 $\mathrm{x}$ DRCR4 (30.85 \%) and DRGR2572 X M5 $(32.78 \%)$.

Table.1 Percentage heterosis and inbreeding depression of eight quantitative characters

\begin{tabular}{|c|c|c|c|c|}
\hline \multirow{2}{*}{ Character } & \multirow{2}{*}{ Cross } & \multicolumn{2}{|c|}{ Heterosis } & \multirow{2}{*}{$\begin{array}{c}\begin{array}{c}\text { Inbreeding depression } \\
(\%)\end{array} \\
\mathbf{F}_{2}\end{array}$} \\
\hline & & $\begin{array}{c}\text { Hmp } \\
(\%)\end{array}$ & $\begin{array}{l}\text { Hbp } \\
(\%)\end{array}$ & \\
\hline \multirow{2}{*}{$\begin{array}{l}\text { Seed cotton yield per } \\
\text { plant }\end{array}$} & $\begin{array}{c}\text { DSMR10 X } \\
\text { DRCR4 }\end{array}$ & $54.26^{* *}$ & $40.79 * *$ & $37.21 * *$ \\
\hline & DRGR2572 X M5 & $55.33 * *$ & $40.27 * *$ & $29.82 * *$ \\
\hline \multirow[t]{2}{*}{ Number of bolls per plant } & $\begin{array}{l}\text { DSMR10 X } \\
\text { DRCR4 }\end{array}$ & $35.45 * *$ & $45.56^{* *}$ & $35.45^{* *}$ \\
\hline & DRGR2572 X M5 & $54.15 * *$ & $46.34^{* *}$ & $20.31 * *$ \\
\hline \multirow{2}{*}{ Boll weight } & $\begin{array}{l}\text { DSMR10 X } \\
\text { DRCR4 }\end{array}$ & $3.60 * *$ & $-3.42 *$ & $6.98 * *$ \\
\hline & DRGR2572 X M5 & $-5.65 * *$ & $-8.13 * *$ & 1.43 \\
\hline \multirow{2}{*}{ Ginning out turn } & $\begin{array}{c}\text { DSMR10 X } \\
\text { DRCR4 }\end{array}$ & $9.89^{* *}$ & $9.62 * *$ & $7.51 * *$ \\
\hline & DRGR2572 X M5 & $7.35^{* *}$ & $8.50^{* *}$ & $7.49 * *$ \\
\hline \multirow[t]{2}{*}{ Lint index } & $\begin{array}{l}\text { DSMR10 X } \\
\text { DRCR4 }\end{array}$ & $31.38 * *$ & $28.54 * *$ & $30.85^{* *}$ \\
\hline & DRGR2572 X M5 & $32.53 * *$ & $33.81 * *$ & $32.78 * *$ \\
\hline \multirow[t]{2}{*}{ Seed index } & $\begin{array}{c}\text { DSMR10 X } \\
\text { DRCR4 }\end{array}$ & $13.19^{* *}$ & $11.15^{* *}$ & $21.71 * *$ \\
\hline & DRGR2572 X M5 & $18.52 * *$ & $17.72 * *$ & $24.03 * *$ \\
\hline \multirow{2}{*}{$\begin{array}{l}\text { No. of Sympodia per } \\
\text { plant }\end{array}$} & $\begin{array}{c}\text { DSMR10 X } \\
\text { DRCR4 }\end{array}$ & -0.75 & -2.21 & $12.49^{*}$ \\
\hline & DRGR2572 X M5 & $23.1^{* *}$ & $36.16^{* *}$ & $18.92 * *$ \\
\hline \multirow[t]{2}{*}{ Plant height } & $\begin{array}{c}\text { DSMR10 X } \\
\text { DRCR4 }\end{array}$ & $5.82 *$ & 6.92 & $16.56^{* *}$ \\
\hline & DRGR2572 X M5 & $25.74 * *$ & $26.10 * *$ & $27.8 * *$ \\
\hline
\end{tabular}

For seed index mid-parent heterosis (13.19\%) and heterobeltiosis $(11.15 \%)$ were both highly significant in cross DSMR10 $\mathrm{x}$ DRCR4, in cross DRGR2572 X M5 both mid-parent heterosis $(18.52 \%)$ and heterobeltiosis $(17.72 \%)$ were also found to be highly significant. Similar results were observed by Shinde and Mehetre (2002) and Shastri (2003). Inbreeding depression in $\mathrm{F}_{2}$ was significant in both crosses, $21.71 \%$ in DRCR4 X DSMR10 and $24.03 \%$ in cross DRGR2572 X M5.

Both mid-parent heterosis and better parent 
heterosis for number of sympodia per plant were non-significant in nature in cross DSMR10 $x$ DRCR4 and significant midparent heterosis $(23.10 \%)$, better parent heterosis $(36.16 \%)$ was observed in cross DRGR2572 X M5. Similar observations were made by Patil et al., (2009) and Wankhade et al., (2009). Significant inbreeding depression was observed in both cross $F_{1}$ to $F_{2}, 12.49 \%$ in cross DSMR10 x DRCR4 and $18.92 \%$ in cross DRGR2572 X M5. Similar results were obtained by Anuradha (1997), Shinde and Mehetre (2002) and Mahantesh Shastri (2003).

Plant height showed significant positive heterosis over mid-parent $(25.74 \%)$ and heterobeltiosis $(26.10 \%)$ in cross DRGR2572 $X$ M5. Similar results were noticed by Maisuria et al., (2006) and Wankhade et al., (2009). Mid parent heterosis was significant while better parent heterosis was nonsignificant in cross DSMR10 x DRCR4. Inbreeding depression from $F_{1}$ to $F_{2}$ was $16.56 \%$ in cross DSMR10 x DRCR4 and $27.80 \%$ in cross DRGR2572 X M5. Anuradha (1997) and Shinde and Mehetre (2002) also observed positive inbreeding depression.

The two cross combinations showed significant positive heterosis for seed cotton yield and its component traits viz., number bolls/plant, number of sympodia and ginning outturn. Seth and Singh (1984) suggested that improvement in seed cotton yield could be achieved by giving due weightage to number of branches and number of bolls.

Significant heterosis and inbreeding depression was observed for all the characters studied in both crosses revealing that, characters are controlled by non-additive gene action and can be exploited for hybrid development. For varietal development, selection should be delayed upto $F_{6}$ generation, because values are not reliable in early generations.

References

Ahuja, S. L., and Tuteja O. P., 2000. Heterosis and combining ability for yield and its component traits in upland cotton. J. Cotton Res. Dev. 14(2):138142.

Anuradha, B., 1998. Genetic studies in compact cotton genotypes (Gossypium hirsutum L.) M.Sc. (Agri.) Thesis, Univ. Agric. Sci., Dharwad.

Dukre, V. B., Burghate, S. K. and Patil, S. P., 2009. Diallel analysis for heterosis studies in upland cotton. J. Cotton Res. Dev., 23(2): 217-221.

Fehr, W.R., 1987. Heterosis. Principles of cullivars development. McMillan. Pub. Co. Inc. New York, 1: 115-119.

Kumari B., Kajjidoni, S. T., Salimath, P.M. and Patil Malagouda, 2009. Heterosis and inbreeding depression for economic traits in desi cotton. Electronic J. Plant Breed, 1: 47-51.

Mahantesh Shastri, 2004. Genetic evaluation of diverse cotton (Gossypium hirsutum L.). Plant types and their segregating generations. M. Sc. (Agri.) Thesis, Univ. Agric. Sci., Dharwad.

Maisuria, A. T., Patel, J. C., Patel, K. G. and Solanki, B. G., 2006. Study of best per se performance, heterosis and combining ability effects for seed cotton yield and its component characters through GMS system in Asiatic cotton. J. Indian Soc. Cotton Improv, 31 (2):8891.

Maisuria, A. T., Patel, J. C., Patel, K. G., Patel, D. H. and Chhimpi, B. G., 2007. Heterosis for yield and its contributing characters in GMS based asiatic cotton. J. Indian Soc. Cotton Improv, 32(1): 3040.

Patel, G. S., and Pethani, K. V., 1998. Studies on heterosis for quantitative characters 
over environments in desi cotton (Gossypium arboreum L.). J. Indian Soc. Cotton Improv. 23(1): 54-59.

Patil, A. J., and Meshram, L. D., 2002. Genetics of boll number in Gossypium hirsutum, L. through triallel analysis. J. Cotton Res. Develop., 14 (1): 23-26.

Patil, S. S., Gavit, A. F., Magar, N. M. and Pawar, N. Y., 2009. Heterosis in hybrids of Gossypium arboreum cotton. J. Cotton Res. Dev., 23(2): 209-212.

Pradeep, T., Laxman, S. and Sumalini, K., (2003), Heterosis and inbreeding depression in intra and interspecific crosses of diploid cotton. J. Indian Soc. Cotton Improv, 34 (1): 41-44.

Seth, S., and Singh D.P., 1984. Studies on heritability and variability for yield components in upland cotton (Gossypium hirsutum L.). Haryana Univ. Agric. J. Res. 14(3): 313-317.
Shinde, S. K., and Mehetre, S. S., 2002. Inbreeding depression for seed cotton yield of intra and inter-specific hybrids. J. Indian Soc. Cotton Improv, pp: 156159.

Tuteja, O. P., Singh D. P., Narula, A. M., Singh, U. V., 2000. Studies on heterosis for yield and quality characters over environment in desi cotton hybrids based on CMS system. J. Indian Soc. Cotton Improv. 25(2): 23-28.

Tuteja, O. P., Verma, S. K. and Ahuja, S. L., 2004. Estimation of heterosis for seed cotton yield and its component characters in G. hirsutum L. J. Cotton Res. Dev. 18: 38-41.

Wankhade, S. N., Patil, S. P., Burghate, S. K. and Chikhale, N. J., 2009. Heterosis for seed cotton yield and its quantitative characters of Gossypium hirsutum L. J. Cotton Res. Dev., 23(1): 27-31.

\section{How to cite this article:}

Aman Tigga, S.S. Patil, Vinayak Edke, Utpal Roy and Ashutosh Kumar. 2017. Heterosis and Inbreeding Depression for Seed Cotton Yield and Yield Attributing Traits in Intrahirsutum ( $G$. hirsutum L. X G. hirsutum L.) Hybrids of Cotton. Int.J.Curr.Microbiol.App.Sci. 6(10): 28832887. doi: https://doi.org/10.20546/ijcmas.2017.610.339 